4. Челишева И.Л. Метод проектов как мотивация учебной деятельности и способ формирования творческой личности учащихся // Русский язык и литература в учебных заведениях. - 2009.- № 3. - С. 36 - 39.

5. Чечель И.Д. Метод проектов, или Попытка избавить учителя от обязанностей всезнающего оракула. Чечель И.Д. // Директор школы, 1998, №3 1.

\title{
Роль кумысолечения в формировании питания школьников
}

\author{
Софронова В.А., студентка, \\ Северо-Восточный федеральный университет, \\ 2. Якутск \\ E-mail: sovaan97@mail.ru
}

Научный руководитель: к.n.н., доцент Егорова Р.И.

Проблема сохранения и развития здоровья подрастающего поколения приобрела статус приоритетной в ряду глобальных проблем.

Работа с социально-проблемными детьми является гармоничным продолжением образовательного процесса и деятельности педагогического коллектива школы по развитию каждого обучающегося, его способности к заполнению досугово пространства общественно-полезной, благотворительной, музыкально-просветительской деятельностью, формированию вкуса к активному отдыху. В последнее время уровень здоровья детей снижается. Особенно ухудшается в период обучения. У учащихся отсутствует стойкая мотивация на «здоровый образ жизни». Поиск путей ее решения способствовало развитию новых областей знания, таких как медицинская география и другое, возникающих на стыке различных дисциплин.

Традиции народа Саха накоплены в различных культурах народа. Сегодня учащиеся мало приобщены к духовному наследию предков, к национальной пище, что заставляют пережить регресс гуманности. Воспитывать детей на традициях кумысолечения послужит здоровому питанию и лечению здоровья одновременно.

Понятие кумысолечении

Наши предки соблюдали традиции предков, что зимой есть мясо, а летом употребляли только молочные продукты, и кумыс для очищения организма. Кобылье молоко - кумыс содержит 40 биологических компонентов, необходимых человеку, витамины, различные минеральные вещества, аминокислоты, микроэлементы и ферменты.

Кумыс - пенящийся напиток приятного кисловатого запаха и вкуса, приготавливаемый путем брожения из кобыльего молока.

Влияние кумыса на здоровье подрастающего поколения:

- Позволяет сопротивляться организму, иммунитету;

- Нормализует обмен веществ, приводя в норму производство гормонов, улучшая процесс пищеварения;

- Борется укреплению кишечную флору;

- Ускоряет регенерацию тканей поврежденных органов;

- Улучшает состояние костной, хрящевой и соединительной тканей; 
- $\quad$ Омолаживает организм;

- $\quad$ Регеанирует кровообращение;

• Предупреждает развитие онкологических и простудных заболеваний;

- Улучшает работоспособность;

Цель исследования - доказать эффективность внедрения национального напитка кумыса.

Школьникам был внедрен национальный напиток кумыс. Каждый день ученикам мы внедрили 400 грамм кобыльего молока днем и вечером. Вне учебы дети пьют кумыс 3 раза в неделю.

Для достижения цели и эффективности был сбор информации роста и веса. А также общее состояние детей и физическая подготовленность.

Был проведен соцопрос, цель которого заключается в межличностном отношении детей. В результате анкетирования по полученным данным можно сделать следующие выводы: взаимоотношения в коллективе положительное, большинство детей удовлетворены своим коллективом, отрицательных взаимоотношений в коллективе не наблюдается.

Анализ и выводы эффективности внедрения национального кумыса

За период исследования результаты в весе в росте общему состоянию здоровья детей улучшилось, что свидетельствует о том, что национальный напиток кумыс способствует развитию веса и роста, улучшается аппетит, секреция желудочного сока и усвоение пищи. Он показывает возбуждающее действие на желудочное - кишечную секрецию, в некотором отношении способен заменять солярную кислоту при недостатке ее в желудочном соке, более легко переваривается и лучше усваивается, чем молоко. Кроме того, при питье кумыса повышается усвоение жиров и белков. После двухмесячного потребления кумыса вес детей увеличился от 4 до 8 кг, что составляет $67 \%$. Медработники считают, что в улучшении здоровья детей большую роль играли соблюдение режима дня, рационное питание кумысом, закаливание на свежем воздухе, купание на реке.

\section{Список литературы:}

1. Волков П.Г. Двигательная активность и рациональное питание школьников. // Теория и практика/ Н.И. Волков. - 2001, № 8. - с. 7 - 18.

2. Михайлов П.М. Кумыс и кумысолечение (В условиях Сибири и Бурятии) / М.П. Михайлов. - Верхнеудинск: Типография Бургосид, 1929. - 46с.

3. Серошевский В.Л. Якуты. Опыт этнографического исследования / В.Л. Серошевский. 2-е изд. - М.: РОССПЭН, 1993. - 197 с.

4. http://www.doctorate.ru/kumiss-therapy-tuberculosis/

5. http://www.doctorate.ru/page/83/ 